\title{
Revisiting the Importance of Cultural Approaches and Values in the International Affairs
}

\author{
Muhammad Mussa Khan ${ }^{1}$, Riaz Ahmad*2, Tahir Mahmood Azad $^{3} \&$ Moldalieva Nargiza ${ }^{4}$ \\ 1. College of Media \& International Culture, Zhejiang University, Hangzhou, China. \\ 2. School of Public Policy \& Administration, Xi'an Jiaotong University, Shaanxi, China. \\ 3. Centre for Science \& Security Studies, War Studies Department, King's College, \\ London, United Kingdom. \\ 4. School of Public Affairs, Zhejiang University, Hangzhou, China.
}

\begin{abstract}
It is claimed that international relations are based on intercultural ties between nations of the states. Culture and international relations are becoming increasingly interdependent of each other. As international relations are the links between the nations, and the nations are bound by different cultures. This paper discusses the importance of culture in international affairs. It evaluates the previous literature and other secondary sources to analyse the prominent role of culture and cultural diplomacy in foreign policy and international affairs. It sheds light on the history that how culture influences other nations and how it is used in the current time. The paper further discusses that culture plays a vital role in resolution of conflicts and harvest peace and cooperation among nations at times of peace and conflict. This also stresses that global actors (leaders and institutions) should value the elements of local cultures in policy-making, even organizations doing business on foreign lands. Such considerations are essential not only in policy making but also in doing businesses.
\end{abstract}

Keywords: International Affairs, Diplomacy, Local Culture, Culture and Peace, Conflict and Peace, Foreign Policy.

\section{Introduction}

The international relations are, by definition, the links between nations (Iriye, 1979), and all nations across the globe are bound by their shared values and cultures. Therefore, this makes it an important factor in the study and interpretation of international relations. At an unprecedented rate, modern diplomacy is witnessing profound changes, changing the very essence of diplomacy as we know it. These developments affect domestic and foreign affairs which once had no major diplomatic concern. International affairs are not solely based on politics and economics but provides a transnational element of people-to-people and culture (Reiterer, 2014; Zhao et al., 2019). Culture has a profound influence across several different aspects of human life, from political and cultural beliefs to religious and social behaviours. This affects the way politicians and strategists think about war and peace issues, since a better understanding of cultural issues will avoid mistakes and encourage national goals to be achieved (Marcos, 2016). Culture is an essential concept in international affairs, especially in foreign policy (Ferguson, 2001). Does culture matter? It is claimed that this is meaningless 
since states and many companies behave according to their interests. Specifically, rationalist scholars believe that egoism is an important key to understanding human nature and state behaviour. There are, however, some cases where states can make different decisions and take divergent actions while pursuing similar interests and working towards comparable goals and objectives (Yaqing, 2012).

Culture has been used as a mean for leaders and countries to demonstrate who they are, claim their influence and create enduring relationships, from the mutual gifts of ancient rulers to modern-day expositions. Within foreign policy, however, which is too often driven by realpolitik thought, culture and cultural exchange are also considered lucrative. A common view is that cultural diplomacy can help establish and facilitate country-to-country relationships. In addition, culture has a critical role to play in foreign affairs today, more than ever before. This comes from the broader, connective and individual ideals that culture has. It is both the medium by which we come to understand others, and an element of life that we love and seek out with intrinsic merit. Cultural exchange gives us the opportunity to appreciate points of cohesion, and to understand the motivations that underlie them where there are differences. Thanks to the growing impact of identity politics on domestic and foreign exchanges, these qualities make culture a vital medium for negotiation and a source of communication in finding common solutions (Bound et al., 2007).

Culture is the human made component of the environment at the grass root level which can be expressed and transmitted and which also provides the patterns, definitions and awareness of human behaviour and in relation to the rest of the world (Ferguson, 2001). When more countries, citizens, and communities adjust to the ever-changing international community, ambassadors, leaders, and representatives meet and deal with other nations' needs and wants. Multiple forms of diplomacy can be exercised; by peace talks, written constitutions, and field observations, etc. Culture is a common concept and by nature it remains unchanged. Struggling for peace; changing cultural expectations and needs. Long-standing customs and traditions are discarded and new practices are implemented, while globalization does promote diplomacy (Matthes, 2010). There are many studies which underline that culture plays a crucial role in foreign relations. This paper reviews the literature and other secondary sources to examine the prominent role that culture plays in international relations and that why it is important to recognize cultural aspects in foreign policy development?

\section{Perception of Culture in International Relations Literature}

The scholarship related to international relations, economics and security studies is the current fad of culture. A multitude of recent books and papers appeal to culture as the underlying force that urges governments, other organizations and individuals to act and coordinate. Many of these studies claim that the value of culture is increasing. The idea that culture influences the actions of people is obviously hardly new. Findings about the relative strengths and behavioural patterns of different cultures are as old as human history. The relatively good economic benefits of the Evangelical and Catholic cultures are studied in modern times by Max Weber (1958); Adda Bozeman (1960) and others, who focuses on the role of culture as a national decisionmaker, Lucian Pye and Sydney Verba (2015), who links up national culture with growth, and Leonardi et al. (2001). However, some of the literature examined here shows that with the end of the Cold War, the cultural forces have become influential in foreign relations, the prime movers of world affairs. Instead of being the more global (and obviously right one), culture is a significant or notable element in international affairs that is being discussed here. 
The culture began to travel as the earliest connections between countries/states/regions arose; when in ancient Greece Porto-states were formed. Culture has migrated through commerce, conquest, and migration. Diplomats carried messages at the time, and the best of them brought new knowledge and skills. They also introduced their own culture to foreign countries. This was also achieved through the traditional exchange of gifts - a custom which was renowned in ancient times and which was aimed at building mutual trust and the spirit of cooperation (Stelowska, 2015). In the studies of 1940s and 1950s, the importance of culture as part of a country's foreign policy played a significant role. Global cultural policy was also referred to as a form of inter-national dialogue. Yet culture as a soft-power lost its influence in international studies during the Cold War ( $\mathrm{Li}, 2018)$. Alternatively, cultural issues were delegated and studied within the broad fields of anthropology, sociology, social psychology, or linguistics, even though they affected nation-to-nation relations. For many languages, the study of foreign policy primarily cultural aspects is not even conceptually clearly described. For example, English has no distinct notion to it. Instead, scholars refer to it as 'cultural relations' or 'cultural diplomacy' or simply using a concise mix of words, i.e., 'culture and foreign relations.' The word content varies depending on the focus that its user sets. International cultural policy is just another instrument in the diplomatic arsenal of a government, which enables it to achieve its foreign policy goals. International cultural policy is reverence for cultural values and customs, a picture of how a nation sees itself and how it expresses itself internationally (Miller \& Yudice, 2002).

In spite of these differences, international cultural policy is usually viewed as being part of a country's foreign relations, and high-ranking policymakers have acknowledged its importance. Former German Chancellor Willy Brandt has named international cultural policy the "third pillar" of foreign policy-alongside economic policy and peace initiatives. To former US Senator Fulbright, on whose ideas one of America's largest educational exchange programs is established states that "foreign policy cannot be focused solely on military strategy and diplomatic activity in the world today. From now on, the shape of the planet will be far more determined by how effectively we convey our society's principles to others than by our military or diplomatic supremacy " (Martens, n.d.). International cultural policy has also played a role as the subject of legal studies in academia. Studies also concentrate on legal aspects of international cultural policy, such as legal structures, contracts, and agreements between nations about cultural transmission, its basis in the respective national constitutions, the rights and duties of mediator organizations, and the like. These thus have important insights into the legal side of cultural matters and their propagation but do not go beyond jurisprudence. As can be seen clearly in the respective literature, the fields of foreign policy and cultural studies evolved independently of one another. Rarely do foreign policy studies include cultural aspects and their importance for international relations. On the other hand, the various works on culture appear to view its foreign policy importance as negligible.

The study of 'political culture' has become increasingly a subject of social science, but it underlines a different viewpoint again. It focuses on the differences and similarities of singlecountry political cultures, and examines topics such as public mentality and understanding of politics. Although some studies also compare various countries and their respective political cultures, foreign cultural policy is not being considered. The interweaving of culture, foreign policy and international affairs has been studied with growing intensity over the last decade. Various scholars have interpreted the topic of culture in different ways regarding international affairs. For example, Hudson's edition on "Culture and Foreign Policy" provides case studies in which individual states express culture about their foreign policies. These include the US, 
China, the Netherlands and Belarus among others. Nonetheless, the-collection of cases and what they stand for is not discussed as the study does not operate with a basis for comparative analysis. Instead, it addresses single studies and their global cultural policies respectively (Lantis, 2002).

In comparison, Chay's edition (1990) on Culture and International Relations deals with culture from the themes and issues perspective. The contributions cover different facets of culture and their importance to international relations. Here one finds topics like diplomatic history, viewpoint on literacy or music and communication. The contributions in each chapter, however, are not based on single countries or a particular collection of countries, but on large 'cultural regions.' The book contains chapters on Asian culture and foreign affairs, or the international relations tradition of Latin America etc. The work of Jacquin-Berdal, Oros and Verweij on Culture in World Politics (Verweij et al., 1998) is similarly issue-based. From a cultural perspective they approach issues such as conflict resolution, concentrate on cultural dimensions of peacekeeping, and relate culture to power and international negotiations. The Return of Culture and Identity in IR Theory (Lapid \& Kratochwil, 1996) discusses basic definitions and their importance for culture and international relations. Citizenship, nationalism, and gender are discussed in their book notions of identity regarding their importance for cultural relations. Hence, many prominent scholars of international relations also studied the importance of culture in from different aspects.

\section{Research Methodology}

\subsection{Research Design}

A conceptual framework is developed for the study of culture and international affairs in light of the published works. The research is descriptive in nature; articles, books, websites and other secondary sources which are credible have been thoroughly assessed and their main findings have been analyzed. Secondary sources that highlight the importance of culture in the international affairs have been studied systematically and their references are given in the bibliography section.

\subsection{Sources of Data}

Secondary sources such as research articles, review articles, conference papers, working papers, books, government and non-government official websites in addition to dissertations related to cultural practices in international affairs have been extensively studied. Most of the data is obtained from the recently published materials which have advanced and up to date information and concepts related to the topic. Review of the published work offers the opportunity to reflect and synthesize the existing work that eventually provides bases for the advancement of new knowledge. Literature reviews significantly contribute to the development of the field and new theories and findings emerge (Liu et al., 2014).

\subsection{Search Strategy}

Renowned and credible sources of publications have been extensively used for the search of related data such as the Google, Google Scholar, Web of Science, Springer and other major search engines and publishers to make sure that the articles or other secondary published sources are credible. 


\subsection{Data Analysis}

Data, related to cultural practices and its role in international affairs, are evaluated from different perspectives. Literature about the role of culture in international affairs in close connection with public diplomacy, soft power, foreign policy has been extensively searched, evaluated and concluded in this paper.

\section{Role of Culture and Values in International Affairs}

\subsection{Cultural Diplomacy}

The role of cultural traditions, activities, and objects instil with significance have exposed more nuanced command than conventional emphasis on states, leaders, and military (Geertz, 1973). International-relations' scholars are increasingly drawing on interdisciplinary sources for a deeper understanding of cultural crossroads with sociology, history, literary theory, media studies, postcolonial studies, gender studies, and anthropology have resulted in the emergence of new actors, facts, methodologies and hence new issues that shed light on the dynamics of power transitions in international relations (Ahmad et al., 2020; Veeran, 2009). Hence, the study of foreign policy or international affairs is not limited to any particular social science school but is an important topic for all. This study is mainly important in international relations as it forms the basis for international interactions between the states (Hussain, 2011). Cultural diplomacy is a kind of collective diplomacy and soft power that involves "exchanging ideas, knowledge, art and other cultural characteristics between nations and their citizens to foster mutual understanding." The cultural diplomacy's aim is to establish awareness of the nation's cultural values and institutions and to make efforts to create broad support for political and economic objectives. This questionable centenary has prompted the discourse on foreign affairs to treat one of the issues for which it is considered the best to draw historical analogies (Pethiyagoda, 2014).

Basically, there are two premises are the source of cultural diplomacy. Firstly, healthy relationships will take root in fertile understanding and respect. Second, cultural diplomacy is supposed to be one of the most critical points of entry into a society, language, art and education. Cultural diplomacy is based on a variety of structuralist diplomatic interventions. Along with it, soft power, propaganda, branding and public diplomacy can be found. It is the soft power dimension of the hard-power spectrum, since it operates through attraction rather than coercion (Goff, 2017). The word 'cultural diplomacy' is now commonly used both in nation-state foreign affairs practice and in social and cultural context. However, the way this definition is used, precisely what its application entails, why it is relevant or how it works frequently lacks distinct clarification. But most of this indeterminacy emerges from the combination of stricto sensu cultural diplomacy, which is primarily a political activity guided by interests, with cultural ties that appear to be motivated rather than interests by values, mainly exercised by non-state actors. This tendency should pose a major concern for the cultural fields of study, given the existing inter-national cultural ties and cultural practices within nations. However, as a main component of contemporary cultural strategies, they have shown little commitment to cultural diplomacy (Ang et al., 2015).

Along the last decade and a half, there have been various interest groups from experts in international affairs in the topic - the wider field of public diplomacy - with a focus on the development of the so-called 'modern public diplomacy' (Cull, 2009; Hayden, 2012). With 
"critical," we are not simply a disgusting position but a thorough, theoretically considered study which takes into consideration current practices of cultural diplomacy within the social, political and ideological frameworks and looks at dynamic and often conflicting ways of operating. The goal is twofold. To demystify cultural diplomacy, in particular by dissecting the 'hype' which it now follows - particularly as it is focused on the idea of 'soft power;' to precisely grasp how it works in the modern world. Such an assessment will also help understand desired strategy dimensions in the domain and the concern whether there could be anything like a cultural diplomacy which works 'beyond the national interest' when viewed through a culture lens. Throughout its philosophic extension, cultural diplomacy has been promoted as a public diplomatic topic that is more public-oriented than the traditional model, whose "goals" are no longer for other countries as for a varied national and world population and audiences. It is widely seen as a multinational mechanism, involving not only governments and their institutions, but also civil society and/or private sector actors (Cull, 2009), a form of intercultural dialog centred on reciprocity and mutual communication. This word comes from America which was introduced in 1965 in order apparently to address the unfavourable stereotypes linked with the term propaganda, by Edmund Gullion, dean of the Fletcher School of Law and Diplomacy (in Tufts University and founder of the Edward R. Murrow Center) of Public Diplomacy (Cull, 2008). It had become deeply rooted in US popular argumentation and had stretched to Europe and beyond by the current century.

Unlike the cultural diplomacy, the government offices other than foreign ministries gradually took over the practices of public diplomacy and has been implemented in the pursuit of priorities such as national branding and program endorsement. The cultural diplomacy is now also interpreted as a specific type or aspect of public diplomacy, resulting in an ambiguity in the differentiation between the two. The cultural diplomacy's national aspirations are never driven solely by merely instrumental or calculational thoughts. Instead, they are integrated in various beliefs and reactions about the country and its role in the minds of other communities, including 'folk theories' and imperfections which are fairly exempt from the reasoned debate and contemplation. The cultural diplomacy research can be clearly built on a broader interpretation of nationalism and national narratives. It is also a testing field for acceptance between and even across the states. There are significant contradictions between, on the one hand, 'traditional' and cultural diplomacy focused on a social and cultural exchange, such as individuals' responsibilities, collaboratory ventures, etc., and, on the other, sector-based and market rivalry practices within the globalization of cultural fields. Given the widespread existence of activities recently - we have not even discussed the booming area of digital diplomacy - within the domain of cultural diplomacy, it may be valuable to disintegrate the very idea of "cultural diplomacy" and to explore its multi-dimensional modalities, with their different complexities, different incorporations into relevant cultural and specialized domains separately (Ang et al., 2015).

\subsection{Culture and Foreign Policy}

The scholars have heatedly addressed whether and how culture in particular and international relations influence and form the foreign policy of a State. We have seen the resurgence of public safety and foreign policy cultural studies, with the increase of constructivism in international relations in the 1990s, while the culture approach centred on terrorism and globalization in the 2000s. Despite the accomplishment of the cultural approach, conceptualization, evaluation and generalization continue to face theoretical and methodological challenges (Feng \& Feng, 2017). Particularly in foreign policy analysis, there 
are many definitions of culture that have become dominant: culture as the organization, culture as desires of interest, and culture as models for human strategy. Before the 1990s, the bipolarity constraints of the Cold War had left little space for idiosyncratic domestic-level variables like culture to influence foreign policy. Additionally, there are a few works that examine culture and FP with an emphasis different from FPA (Grove, 2010). An analysis of how the actors of the state (political leaders or institutions) make foreign relations decisions has become one of the areas where there has been some attention to recognizing the influence of different cultures (Hudson, 1997b: 4-7), particularly in times of disaster. Apart from human characteristics and psychology, it is also predicted that, politics and systems, in their cultures, their historical backgrounds, language structures and values may influence individuals to some degree (Reents-Budet, 2000). Micro-cultures may be significant here (Hudson, 1997b: 16), e.g., those in unique fields, various policy organizations, study areas, graduates from a particular university (Ferguson, 2001).

However, the governments have also sought to use culture in foreign policy since the 1920s, to promote their own language, music, media and views to the international audience (in the past, this was usually a promotion of high culture). Accordingly, it was understood that there were cultural borderlands where various cultures interrelated with each other, and cultural diplomacy was utilized for strong bilateral relations. Britain and France, in addition to few other nations, have been able to promote their language and culture as part of nation-to-nation diplomacy, such as the British Council's operations worldwide. Similarly, Turkey has tried to take advantage of its position as a cultural boundary between the Central Asia and Europe, aiming to capitalize on its proximity to European markets and technology and cultural ties with the Turks of most of Central Asia (the cultural region known as Turkestan). Culture dealt complicatedly with political legitimacy issues in Asia and had a complicated effect on countries in Eastern Europe, America, and the Middle East (Reents-Budet, 2000). Global organizations, through the growth of cultural internationalism, have always sought to benefit from cultural diplomacy as well. From the 1955 Bandung Conference in Indonesia, the Non-Aligned Movement (NAM, with 113 members) called for active cultural exchange, but this was never followed up, thus not developing strong channels of understanding between Africa, Asia, the Middle East and Latin America that would have strengthened other forms of synergy between them (Ferguson, 2001).

\subsection{Culture and Conflict Resolution}

There are various aspects in which the culture and values decreases or facilitates conflict and cooperation. One of the simplest issues was cultural imperialism, whereby an influential political or economic power would exert its force over others or build dynamics where it prefers its cultural values. This was true in most European empires (including English, Spanish, French, and Netherlands). The US is also seen in the contemporary era as directly and indirectly helping to promote Americanization, primarily through companies distributing cultural goods as well as possessing powerful science, educational, media and publishing platforms. Americanization appears to have been encountered in such diverse cultures as Japan, Austria, Saipan and Australia in several parts (Ferguson, 2001; Khan et al., 2020). It should also be recalled, however, that American culture itself has been greatly enlarged by ethnic influences, much of which have come from Europe since the First World War, and mainly by Latin American, Asian and African cultural outlets. Some would say that American culture has now become quite decentred to a greater extent (Iriye, 1997a), and that what is spreading across the world is something more than an American WASP community. This means there may be more 
connections between goods and local communities, but it does not, of course, allow for a truly broad-based media or multi-value production system (Ferguson, 2001).

Resistance appears to be a useful tactic in many cultures, particularly in the face of world powers. There are many small-scale communities in Africa, Asia and the Pacific that are alive and able to make greater use of their native and Western cultural elements. Similarly, since the 1990s, in many countries, including France, Italy, Hungary, and India, a distinctive resistance to the more superficial elements of global society, often called 'anti-culture' or de-civilizing, has arisen, often dubbed 'culture jamming.' Also, weaker parties, ranging from passive resistance, defiance, non-violent opposition, legal interference, imaginative product readaptation, common aggression, or targeted sabotage to absolute terrorism, use a wide range of forms of resistance (Pettman, 1992). A related concern is the cultural appropriation, where cultural elements may be taken from their collective context and reused in a new way, often as part of an academic or commodified 'good.' A diverse culture has been able to take on, assimilate and use different ideologies (European, Islamic, Hindu, Buddhist,) and turn around and enter into an entertaining debate with the world, often in one presentation using three languages (e.g., English, Japanese and Indonesian). In Bali, the learning and amusement are typically combined for several things (Knutagard, 1996). Some elements of the dance-music culture are readily accessible only to visitors, but luckily the larger community that sustains these artistic products remains vibrant and only partly dependent on the tourist industry.

The visitor money and UNESCO funds have helped to preserve and protect major world monuments, e.g., Buddhist sites in Sri Lanka apparently balancing the needs of local residents and tourists as well (Otchet, 1998). Not all other cultures, notably native ones, have retained such considerable balance, and in many cases, local communities have to strive to rescue a heritage and culture from extinction (Gibbs, 1991). The culture, values, and its 'relics' are in many cases plundered, with experts seeking to 'pass the other civilizations' (Knutagard, 1996). Too often this information is viewed as a form of control that a dominant group can take on and use (Ferguson, 2001). Another concern that arose in the twentieth century was that culture was increasingly politicized. In other words, powerful nations have regarded themselves as guardians of a specific civilization (Germany, France, United States, Soviet Union, $19^{\text {th }}$ century China, Egypt, Iran, etc.). This meant they could easily claim that every nation was 'fighting for its religion' which turned into war (Iriye, 1997b). This meant that confrontation could easily be taken to a political level, the survival of a superior culture against one that was considered to be inferior (For example NAZI propaganda against the Soviets), the survival of a strong AngloAmerican society (Churchill's view of World War II), the survival of socialism across the globe (the Soviet Union's Brezhnev doctrine), or the defence of religious rebellion.

Prolonged conflicts also involve a non-material aspect, as they become key elements in the sense of identity of the opposing states, and as societies develop strong views about the conflict over time, which help to maintain it over time. This non-material aspect of foreign conflicts can be influenced and modified by culture. This is due in large part to the unique features of cultural tools that can touch a wide number of people and transmit knowledge and emotions that would possibly avoid conflict. Ensuring the peaceful emergence of new great powers requires greater in-depth and coordinated efforts by Western governments to understand Asia's and other cultures. Foreign policy is once again becoming a game of big stakes for the leaders. Western diplomatic services are starting to understand the need for greater country experts and academic contact. Most of the mass media is still pausing behind however (Pethiyagoda, 2014). Culture matters in all policy making, most particularly in foreign policy and international 
relations. In fact, Chinese culture's four essential elements; contextuality, correlativity, complementarity, and changeability continue to work in today's era of complex environments (Yaqing, 2012). Only one hundred years ago, the League of Nations did not survive with the disengagement of a then growing America, the current international structure and its key institutions could not withstand disengagement by the emerging powers of today. The restoration of culture is not just a discussion about academics. If statesmen in a multipolar world deal with the major issues of global security and development, culture is the 'wildcard' that they cannot overlook (Pethiyagoda, 2014).

\subsection{Cultural Values and Globalisation}

Culture is used in many different ways by diplomats (Bolewski \& Kennedy, 2008). In the Beijing Palace Museum, a selection of watches and clocks from the seventeenth and eighteenth centuries shows some of the impacts that can be traced back to historical events. The collection contains prestigious British clocks and watches which are provided by visiting emissaries to China. It is one of the most preferred international collections in China, and is visited by Western cultural experts, including British Museum scholars who have reported and studied it in great detail. The clocks and watches were originally intended to please Chinese dignitaries who had shown a fascination with automatons. But those clocks also displayed British manufacturing prowess and symbolized British values: its tradition of invention and precision, and its mastery of nature and time. The clocks express ideals and talk to people in ways that are more discreet and less intrusive than overt propaganda - much like images, films and scientific projects (Bound et al., 2007).

Despite these common implications, some might argue globalization would also strengthen local communities. Satellite TV, for example, made an expansion in the proportion of regional channels in India, many of which telecast Indian stuff, which offers new opportunities for an Indian to connect with his local ties (Wang, 2007). Similarly, multinational corporations must take into account the cultural values of all the countries in which they run businesses and sell goods. This can also aid in creating cultural understanding. Some spectators have hypothesized that some of the similar effects of globalization on national cultures potentially appear to generate a reaction among indigenous peoples that might lead those whose cultures are afraid to reaffirm their own local customs. United Nation in this regard is playing a very positive role to protect the historical sites of the local culture, but this is not enough, there is a need that states devise policies for the multinational corporations to respect and value the elements of local culture.

\section{Conclusion}

Culture's role in the development or execution of foreign policy cannot be overlooked. Its significance has been experienced in history to this day, and it continues to be increasingly significant in the coming period. To date, most non-Western countries have functioned significantly using European-sourced governance structures, making their foreign policies at least somewhat transparent to policymakers of other countries. Cultural principles may have more effect than just the actions of the states making their foreign policies. The ultimate aim of cultural diplomacy and its approaches primarily encourage overseas audiences and use the same strength that is built up over the long term as a source of good will, reserve to gain policy support. It seeks to connect the elements of culture to induce foreigners to have a positive view of the citizens, culture, and policies of the country, and encourage greater cooperation among 
nations. Cultural diplomacy research can clearly build on a broader interpretation of nationalism and national narratives: it is also a testing field for acceptance between and even across states. In addition, it helps change the selected nation's policies or political environment and avoid, manage, and diminish conflict with other nations. This paper stresses that global actors (leaders and institutions) should value the elements of local cultures in policy-making, even organizations doing business on foreign lands.

\section{References}

Ahmad, R., Gul, A., \& Khan, M. M. (2020). India and the US as enduring global partners: an assessment. Journal of Public Affairs, 20(3), e2094.

Ang, I., Isar, Y. R., \& Mar, P. (2015). Cultural diplomacy: beyond the national interest? International Journal of Cultural Policy, 21(4), 365-381.

Bolewski, W., \& Kennedy, J. F. (2008). Diplomatic processes and cultural variations: the relevance of culture in diplomacy. The Whitehead Journal of Diplomacy and International Relations, 145-160. https://www.law.upenn.edu/live/files/5460bolewski----diplomatic-processes-and-cultural

Bound, K., Briggs, R., Holden, J., \& Jones, S. (2007). Culture is a central component of international relations: it's time to unlock its full potential. https://www.culturehive.co.uk/wp-content/uploads/2013/04/Demos-Culturaldiplomacy-report.pdf

Bozeman, A. (1960). Culture and politics in international history. Princeton University.

Chay, J. (1990). Culture and international relations. Praeger.

Cull, N. J. (2008). Public diplomacy before Gullion: the evolution of a phrase. In: Routledge handbook of public diplomacy (pp. 39-43). Routledge.

Cull, N. J. (2009). Public diplomacy: lessons from the past (No. s 12). Figueroa Press.

Feng, H., \& Feng, H. (2017). Cultural influences on foreign policy. In: Oxford Research Encyclopedia of Politics. Oxford University. https://doi.org/10.1093/acrefore/9780190228637.013.404

Ferguson, J. (2001). The controversial role of culture in international relations. The Department of International Relations, Bond University, Australia http://www.international-relations.com/wbadvir/wbadvir4.htm

Geertz, C. (1973). The interpretation of cultures. Basic Books.

Gibbs, A. (1991). Cultural and political limitations within a rational approach towards educational change. Journal of Advanced Nursing, 16(2), 182-186.

Goff, P. M. (2017). Cultural diplomacy. In: The Oxford handbook of modern diplomacy.

Grove, A. (2010). Culture and foreign policy analysis. In: International Studies Association and Oxford University. https://doi.org/10.1093/ACREFORE/9780190846626.013.381

Hayden, C. (2012). The rhetoric of soft power: public diplomacy in global contexts. Lexington Books.

Hussain, Z. Z. (2011). The effect of domestic politics on foreign policy decision making. http://www.e-ir.info/2011/02/07/the-effect-of-domestic-politics-on-foreign-policydecision-making/

Iriye, A. (1997a). Cultural internationalism and world order. The John Hopkins University. https://jhupbooks.press.jhu.edu/title/cultural-internationalism-and-world-order

Iriye, A. (1997b). OSS in China: prelude to cold war: Yale University. https://doi.org/10.1080/03612759.1997.10525313 
Iriye, A. (1979). Culture and power: international relations as intercultural relations. Diplomatic History, 3(2), 115-128. $\quad$ https://doi.org/10.1111/j.14677709.1979.tb00305.x

Knutagard, H. (1996). New trends in European youth and drug cultures. Paper presented at the Youth '95 symposium (1995: Hobart). Youth Studies Australia, 15(2), 37-42. https://search.informit.com.au/documentSummary;dn=970100900;res=IELAPA;typ $\underline{\mathrm{e}=\mathrm{pdf}}$

Khan, M. M., Ahmad, R., \& Fernald, L. W. (2020). Diplomacy and education: a systematic review of literature. Global Social Sciences Review, 5(3), 1-9. https://doi.org/10.31703/gssr.2020(V-III).01

Lantis, J. S. (2002). Strategic culture and national security policy. International Studies Review, 4, 87-113. https://doi.org/10.2307/3186465

Lapid, Y., \& Kratochwil, F. V. (1996). The return of culture and identity in IR theory. Lynne Rienner.

https://www.rienner.com/title/the return_of_culture_and_identity_in_ir_theory

Leonardi, R., Nanetti, R. Y., \& Putnam, R. D. (2001). Making democracy work: civic traditions in modern Italy. Princeton University.

Li, E. (2018). The Rise and fall of soft power. Foreign Policy. https://foreignpolicy.com/2018/08/20/the-rise-and-fall-of-soft-power/

Liu, C., Kuang, Y., Huang, N. and Liu, X. (2014) An empirical research on evaluation of lowcarbon economy in Guangdong Province, China: Based on "Production, Life and Environment". Low Carbon Economy, 5, 139-152. https://doi.org/10.4236/lce.2014.54015

Marcos, D. (2016). Ideas, beliefs, strategic culture, and foreign policy: understanding Brazil's geopolitical thought. University of Central Florida. https://stars.library.ucf.edu/cgi/viewcontent.cgi?article $=6105 \&$ context=etd

Martens, K. (n.d.). Culture and foreign policy: a comparative study of Britain, France and Germany. $\quad$ https://ecpr.eu/Filestore/PaperProposal/271539ad-35a6-4837-82b78b86a3b6d092.pdf

Matthes, D. (2010). Culture, globalization, and international relations. International Symposium on Cultural Diplomacy, 01-05. http://www.culturaldiplomacy.org/academy/content/articles/symposium2010/partici pant-papers/Danielle_Matthes___Usa.pdf

Miller, T., \& Yudice, G. (2002). Introduction: the history and theory of cultural policy. In Cultural Policy. Sage. https://sk.sagepub.com/books/cultural-policy/n1.xml

Otchet, L. (1998). The knowledge economy: when ideas are capital. https://unesdoc.unesco.org/ark:/48223/pf0000114252

Pethiyagoda, K. (2014). Why cultural values cannot be ignored in international relations. East Asia Forum. http://www.eastasiaforum.org/2014/09/20/why-cultural-values-cannotbe-ignored-in-international-relations/

Pettman, I. (1992). New library world: vision, virtual reality and reality. New Library World, 93(1). https://doi.org/10.1108/EUM0000000002416

Press-Barnathan, G. (2017). Thinking about the role of popular culture in international conflicts. International Studies Review, 19(2), 166-184. https://doi.org/10.1093/isr/viw030

Pye, L. W., \& Verba, S. (2015). Political culture and political development. Princeton University. https://press.princeton.edu/books/hardcover/9780691648880/politicalculture-and-political-development 
Reents-Budet, D. (2000). Michael D. Coe \& Justin Kerr. The art of the Maya scribe. London: Thames \& Hudson, 1997; New York: Abrams, 1998. Pp. 240. Hb \$75.00. Language in Society, 29(3), 464-467. https://doi.org/10.1017/S004740450038304X

Reiterer, M. (2014). Role of culture in EU-China relations. The European Foreign Affairs Review, 19. https://heinonline.org/HOL/Page?handle=hein.kluwer/eurofa0019\&id=475\&div=\&c ollection=

Stanzel, V. (2018). New realities in foreign affairs: diplomacy in the 21st century. PLoS ONE, 10(11). Public Library of Science. https://doi.org/10.1371/journal.pone.0142390

Stelowska, D. (2015). Culture in international relations defining cultural diplomacy. Polish Journal of Political Science, 1(3), 50-72.

Veeran, V. E. (2009). The 'cultural turn' in international relations: making sense of world politics. E-International Relations. https://www.e-ir.info/2009/05/10/the-culturalturn-in-international-relations-making-sense-of-world-politics/

Verweij, M., Oros, A., \& Jacquin-Berdal, D. (1998). Culture in world politics. In: Culture in World Politics ( $1^{\text {st }}$ ed.). Palgrave Macmillan UK. https://doi.org/10.1007/978-1-34926778-1_1

Wang, Y. (2007). Globalisation enhances cultural identity. Intercultural Communication Studies, 16(1), 83-86. https://web.uri.edu/iaics/files/09-Yi-Wang.pdf

Weber, M. (1958). The protestant ethic and the spirit of capitalism. Trans. T. Parsons. Charles Scribner's.

Yaqing, Q. (2012). Chinese culture and its implications for foreign policy-making. China Institute of International Studies. http://www.ciis.org.cn/english/201204/12/content_4934865.htm

Zhao, F., Ahmad, R., \& Liao, P. (2019). Cross-cultural adaptation of international talents from the belt and road countries: a case study of Suzhou Vocational University. Arts and Social Sciences Journal, 10(2), 1-6. https://doi.org/10.4172/2151-6200.1000443 